\title{
LOS HIJOS DE LA TIERRA
}

LA CONOUISTA DEL CORAZÓN DEL CHILE

PROFUNDO EN ELFOTOLIBRO PU MAPUCHE

DE LUIS SERGIO

뜯

The children of the earth. The conquest of the heart of deep Chile in the

photobook Pu Mapuche by Luis Sergio

Eluis cáceres álvarez https://orcid.org/0000-0002-1738-5483 Periodista y docente de la Universidad Peruana de Ciencias Aplicadas - UPC pcculcac@upc.edu.pe

\section{RESUMEN}

Este artículo explora la estructura y construcción del fotolibro Pu Mapuche, del fotógrafo peruano chileno Luis Sergio, el cual retrata la vida cotidiana de los habitantes del territorio mapuche en la región de la Araucanía, en Chile.

\section{ABSTRACT}

This article explores the structure and construction of the photo book Pu Mapuche, by the Peruvian Chilean photographer Luis Sergio, which portrays the daily life of the inhabitants of the Mapuche territory in the Araucanía region, in Chile.

\section{Palabras claves:} Pu Mapuche,

Luis Sergio,

fotolibro.

\section{Key words:}

Pu Mapuche,

Luis Sergio,

Luis Sergio,

photobook.

\section{FICHA TÉCNICA:}

Título: Pu Mapuche

Autor: Luis Sergio

Edición y concepto: Jorge Gronemeye

Diseño: Claudia Guerra

Textos: Hernán Curiñir Lincoqueo

$$
\text { Margarita Alvarado }
$$

Bernardita García

Dimensiones: 210 × 163mm / 94 páginas +

cuadernillo inserto de 12 páginas

Número de fotografías: 63 (50 en blanco y negro y

13 en color)

Edición de 500 ejemplares

Editorial: Gronefot, Santiago de Chile, 2018

ISBN: 978-956-9942-00-6

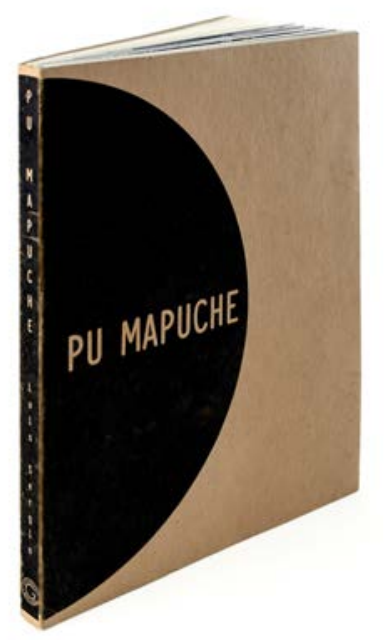

Recibido: 2 de mayo de 2020 / Aprobado: 10 de julio de 2020. 

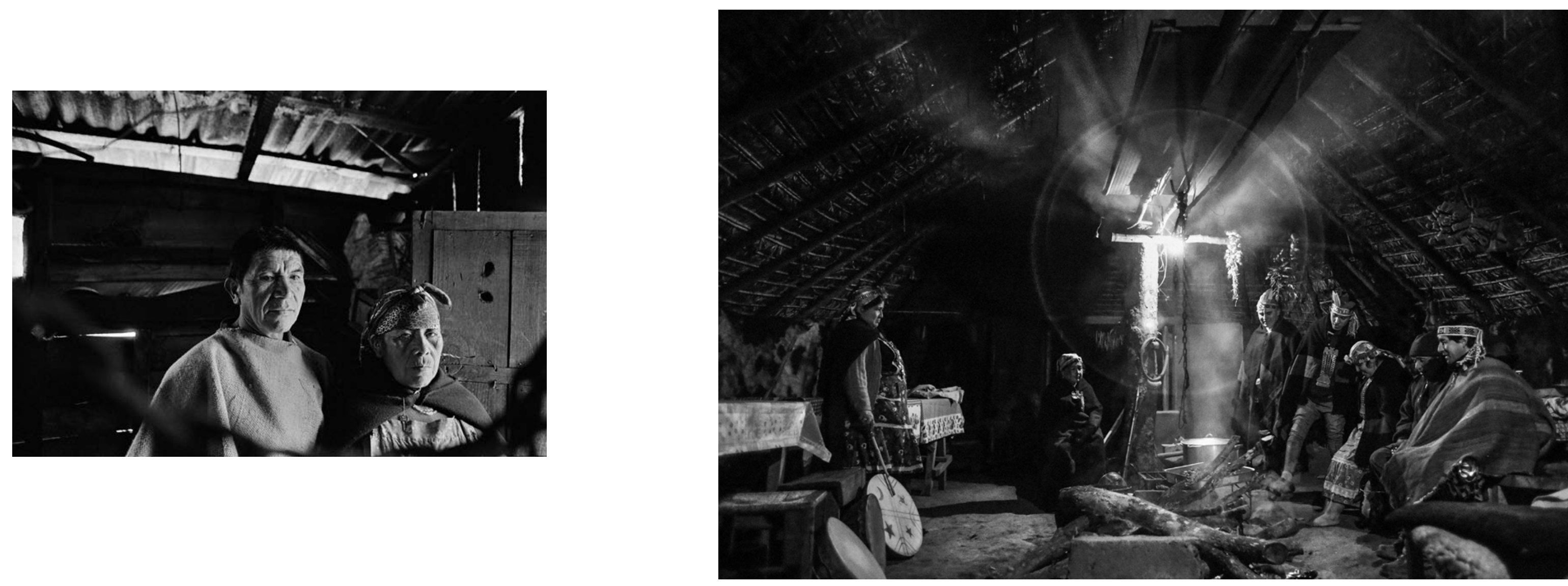

turística y los estereotipos. Desde la observación de los rituales y los distintos estados de la condición humana, refleja lo real maravilloso que encontramos a lo largo de Latinoamérica.

Pu Mapuche se editó por temas en tres extensos segmentos. El primero concerniente a la convive a la convivencia de los adultos en el campo, el segundo sobre los problemas que jóvenes mapuches pasan por defender los bosques tan apreciados por su cultura, y el tercero revela cómo se preserva la identidad tras la migración del campo a la capital con una coda de retratos. Cada capítulo tiene el objetivo de conocer de manera íntima el significado de ser mapuche en el siglo XXI.

La parte lúdica está justo en la mitad. El autor entrega las únicas fotografías a color del trabajo. Está hecha en formato fanzine para que el lector "se identifique" con el aspecto político ¡ las tierras sagradas para la plantación de árboles utilizados en la industria maderera, y la demanda de recuperación de estos terrenos. Este fotolibro muestra el fuego, el regocijo, la mística y la molestia de un grupo humano. Nos acerca valores, mayormente, ocultos en una sociedad urbana cada vez más divorciada de sus raíces rurales. En efecto, el autor nos dice a través de su lente que el contacto transforma, lo que no tenemos el otro sí.

Aunque la presentación de Pu Mapuche lo páginas de este fotolibro demuestran la madurez del fotógrafo. Son imágenes fascinantes en una secuencia narrativa clara que entrega el punto de vista del autor. Por tal motivo, no hay numeración de páginas ni pie de fotos. Solo si el lector desea indagar más, puede ir al final y encontrar el con contrar el contexto de todo loque se fotografió n mapudungun, español e inglés. Cabe resaltar que el autor sigue trabajando para revela a transformación cultural de los mapuches en las principales ciudades de Chile y enriquecer la línea temática.

El 25 de octubre de 2019 la Wenüfoye bandera mapuche- fue protagonista de la marcha más grande de Chile en Santiago. La descha más grande de Chile en Santiago. La desde justicia, dignidad, igualdad, pero, sobre todo, de resistencia. Ese día obtuvo vistas panorámicas desde el inicio del evento, luego, de los rescatistas de salud y los manifestantes heridos y al anochecer, se dedicó a fotografiar las huellas de la marcha. Luis Sergio aún recuerda la imagen emblemática entre banderas ondeantes, cantos y tambores. En la plaza principal, sobre la multitud se alzó un joven descamisado en la cima de una estatua militar, agarrando la Wenufoye mientras el sol resplandecia a su a rededor, los manifestantes gritaron eufóricos por una sociedad mejor. Un ícono. Para una siguiente publicación, será pretexto seguir la historia de ciertos integrantes del pueblo mapuche que participaron de aquel estallido social.

Cuando pase el temblor de la nueva enfermedad en el mundo, apreciar los cambios políticos que quedaron pendientes en el país y cómo estos afectarán a los pueblos originarios, será prioridad. "Chile es andino. Chile es multicultural. Hay que quitarse el complejo de que somos diferentes", afirma el autor. Pu Mapuche sostiene que el chileno más que valorar la cultura mapuche, debe aceptarla tal cual es. Leer/observar las páginas de este fotolibro es una oportunidad para comprender su patrimonio intangible; y como dice la canción un Inca bajó del cielo con tal acento peruano, así que, del Mapocho al Rímac, no perdamos de vista a Luis Sergio mientras camine por el sur. 